\title{
Service development: Modelling influencing factors by employing the Norwegian Coastal Voyage (Hurtigruten) as a case
}

\author{
Hugo Skaalsvik $^{1 *}$ and Jon-Arild Johannessen ${ }^{2}$
}

Received: 14/02/2012 Accepted: 02/11/2012

\footnotetext{
${ }^{1}$ Department of Business Administration and Social Sciences, Harstad University College, Havnegata 5-7, 9480 Harstad, Norway; e-mail: hugo.skalsvik@hih.no

${ }^{2}$ Oslo School of Management, Oslo, Norway, and Harstad University College, Harstad, Norway

* Corresponding author
}

\begin{abstract}
This paper reports research on a service development study carried out on the prestigious Norwegian Coastal Voyage (NCV), also known as the Hurtigruten, which is the brand name. The primary research instrument employed in the research was in-depth interviews with service managers and service personnel employed on the Hurtigruten. This paper reports on findings on influencing factors to service development and suggests how the identified factors influence service development on the Hurtigruten. A model is suggested that depicts these factors, which are grouped into company internal, company external and system factors. The study advances the knowledge field of service development particularly relevant for a high-contact service such as a cruise operation.
\end{abstract}

(C) 2013 International University College. All rights reserved

Keywords: service development, service innovation, qualitative research, case study research, Norwegian Coastal Voyage (NCV), Hurtigruten

Citation: Skaalsvik, H. \& Johannessen, J.-A. (2013). Service development: Modelling influencing factors by employing the Norwegian Coastal Voyage (Hurtigruten) as a case. European Journal of Tourism Research 6(1), 53-73.

\section{Introduction}

Substantial innovation research has been carried out in mostly large manufacturing organisations over the last few decades, but studies on innovation in the service sector have received relatively little attention from academic researchers (Johne and Storey, 1998; de Bretani, 2001; Oke, 2007). However, as Western societies in particular have moved into the "third wave" (Toffler, 1981), the service sector has increased in importance (Kandampully, 2007). The shift from a production- to a knowledge-oriented economy (Kim and Mauborgne, 1999) has been given various labels in the research literature such as the information economy, the service economy, or even the "new economy" (Grönroos, $2000: 11)$. Today, the importance of services in 
industrialised countries is substantial since more than two-thirds of the entire "workforce is employed in services" (Gummesson, 2000:7). Hence, service industries constitute a major part of the total economic activity and employment in Western economies, and the service sector offers a tremendous potential for growth and profitability (Martin and Horne, 1992; de Jong and Vermeulen, 2003; Oke, 2007). In this situation, the requirements for flexibility, speed, renewal, change and innovation in enterprises have enhanced in order to compete effectively in the new marketplace (Trott, 2005).

As associated with economic growth, employment and prosperity in society (Drucker, 1985), innovation has become one of the fastest growing research fields within the management area. Innovation research is a fundamental study of change processes, knowledge development and knowledge integration in social systems (Johannessen et al., 1997:668-669). However, today a new stream of innovation research has gradually emerged in relation to service innovation or service development that reflects the movement of societies into communities of services (Droege et al., 2009). However, according to de Jong and Vermeulen (2003), many service firms struggle with their innovative efforts in competitive environments, which, in its extreme form is termed "hypercompetition" by D'Aveni (1994). Today, service firms are at the heart of many modern societies, but still, many service firms are not very innovative (de Jong and Vermeulen, 2003).

The concepts of service development and service innovation have been applied interchangeably in the research literature (Menor et al., 2002). In this paper, for the most part, the concept service development is employed. The core of the concept is similar to what Leiponen (2005) perceives as a service innovation, which is "new service development which involves changes in the process of delivering existing services and the generation of new services". This definition implies a process view of service development, which is consistent with a systemic approach to the study of innovation (Rothwell, 1992; Trott, 2005).

Service development is considered to be a major challenge, as well as an opportunity faced by service management and marketing managers (Eastingwood, 1986; Johne and Storey, 1998; Sundbo, 1997), due to the process of internationalisation and enhanced competition in an internationally oriented and growing service sector (de Bretani, 1995; Bitner et al., 2000; Lovelock et al., 2001). In order to stay ahead in fierce and global competition, service enterprises have to constantly plan for, develop and implement new services (Edvardsson et al., 1995). However, innovative progress is difficult to accomplish in services (Dörner et al., 2011). One reason for this is that many innovations in services are quite easy to imitate (de Jong and Vermeulen, 2003), with another reason being that the barriers to entry in many services are relatively low (op.cit.). Consequently, service managers need knowledge, skills and competencies on how innovations in services are adequately planned, organised, managed and implemented in their own businesses.

The aim of this paper is to enhance the knowledge base on service development, as more research on this topic in service enterprises is called for (Alam and Perry, 2002; Dörner et al., 2011), which is done by exploring service development on the famous and prestigious Norwegian Coastal Voyage, also known as the Hurtigruten, which is the brand name. As a high-contact- and consumeroriented service, the Hurtigruten is an interesting research setting as the most famous and important tourism attraction product in Norway. In order to examine service development on the Hurtigruten, the research must encompass an historic dimension. As a result of the fact that the tourism dimension of the Hurtigruten increased in importance by the introduction of new and modern explorer cruise ships in the early 1990s, the context of this paper encompasses two shipping lines, which at that time were operating in the Hurtigruten trade: the Troms Fylkes Dampskipsselskap A/S (TFDS) and the Vesteraalen and Ofoten Dampskipsselskap A/S (OVDS). Since the two shipping lines successfully merged in 2006 , the 
research context also encompasses the merged shipping line: the Hurtigruten, ASA (see Appendix 1 for informative details on the Hurtigruten). The choice of a cruise line context for the study is highly relevant, as this industry is in "an early stage of development" (Biederman, 2008:197), with the growth potential being high.

The research addresses two important questions:

1. What key factors influence service development on the Hurtigruten?

2. How do the identified factors influence service development on the Hurtigruten?

To answer the questions posed, the paper is organised in six parts. Following this introduction, Part 2 entails a discussion on a selection of the research literature on service development in service enterprises. In Part 3, the research methodology is presented and discussed, while in Part 4, the findings are presented. Part 5 involves the discussion part, whereas Part 6 outlines the implications and conclusions to be drawn from the study. The limitations of the study are outlined in this part and further research is suggested.

\section{Literature review}

A review of the extant literature on service development reveals a picture of incomplete knowledge (Alam and Perry, 2002). While the academic literature on tangible product development is quite comprehensive and rich, the academic literature on intangible product development is fragmented, short and poorly developed (Dörner et al., 2011). One reason for this could be that the intangible and simultaneous nature of services makes the impact of service development and innovation harder to trace in services than in manufacturing (de Jong and Vermeulen, 2003). Thus, relatively little academic knowledge exists on how service development actually works in service enterprises (Drejer, 2004; Adams et al., 2006; Spohrer, 2008). Consequently, the knowledge base on service development needs to be further developed and advanced (Droege et al., 2009; Dörner et al., 2011). In this part, theoretical- and empirical contributions to service development for the relevance of the research carried out and reported in this paper will be presented and discussed. The research reported on is being carried out at the firm level, with the literature review being organised into three parts. First, the schools of thought in new service development will be described. Second, perspectives and models of innovations will be reviewed, and lastly a section on success factors to service development will end this part of the paper.

Schools of thought in new service development How scientific knowledge on service innovation develops is at the heart of service innovation research (Droege et al., 2009). As one example, Coombs and Miles (2000) suggested three schools of thought in service innovation research: those of assimilation, demarcation and synthesis, all of which have been applied by other researchers as well (e.g. Drejer, 2004; de Vriess, 2006). Similarly, Gallouj (1998) and Sundbo et al. (2007) have suggested three distinct phases of knowledge development on service innovation: those of a technologist-, a demarcation- and a synthesis phase. The core idea of the typologies suggested is to outline and describe the differences which exist on how innovation in services develops and progresses.

In a review of the literature on service innovation, Droege et al. (2009) suggest four schools of thought on service development, a technologist-, assimilation-, demarcation- and synthesis perspective. As is inherent in the name itself, a technologist perspective is linked to the development of technological knowledge and competencies, particularly in relation to progress in information technology (IT). According to Droege et al. (2009), this school of thought is the beginning of a service innovation research stream coupled with Barras' (1986, 1990) reverse product cycle model, which several authors have termed as a technologist approach to knowledge development on service innovation ( Gallouj and Weinstein, 1997; de Vries, 2006 and Sundbo et al., 2007). Nevertheless, according to Droege et al., (2009), this stream of research has been subject to critiques because of the close connection to technology, as many innovations in services are of a nontechnological character (Gallouj, 2002). 
In the service research community, there is an ongoing discussion as to whether concepts and theories developed in manufacturing settings are applicable and transferrable to innovations in services (e.g. Coombs and Miles, 2000; Drejer, 2004 and de Vries 2006). However, at present the "assimilation perspective" seems to be in decline (Droege et al., 2009). One argument is the key role of technological drivers for innovations in the manufacturing sector, while most innovations in services are of a non-technological nature (Gallouj, 2002). The assimilation stream of research is contrasted by a parallel direction, that of a demarcation perspective. The core argument for this perspective is that the distinctive characteristics of services (Hoffman and Bateson, 1997; Lovelock and Wright, 1999; Kandampully, 2007) make it difficult to transfer knowledge acquired from the manufacturing sector to the service sector (Fitzsimmons and Fitzsimmons, 2000). Researchers within the demarcation stream of research rest their research on the idiosyncrasies of services, which implies the creation of unique models of innovations that are valid for services only (Martin and Horne, 1993; de Bretani, 1995; Eastingwood and Storey, 1995). Even so, some researchers argue that the insights and knowledge obtained from research on innovations in services are also applicable and useful to some extent for product innovation in the manufacturing sector (e.g. Gadrey et al., 1995; Den Hertog, 2000; Djellal and Gallouj, 2001). Nonetheless, an emerging trend seems to be an integrative or systemic one. This stream of research is termed as a synthesis perspective, as the research aims to bring together innovations in services and manufacturing sectors instead of separately studying the fields (Gallouj and Weinstein, 1997; Coombs and Miles, 2000, Drejer, 2004; Howells, 2006 and Nijssen et al., 2006). Thus, the present state of knowledge seems to be that of a synthesis perspective, as development in manufacturing and services are filtered together.

\section{Perspectives and models of innovation}

As innovation has been argued to be the engine of growth for a long time (Tidd et al., 2005; Trott, 2005), what "drives" innovation has been a key issue in innovation research. Two perspectives have been given particular attention over the past 15 years, those of a market- and a resource-based view (Trott, 2005).

According to the market-based view, market conditions provide the context which facilitates or hampers the extent of a firm's innovative performance (Narver and Slater, 1990; Slater and Narver, 1994; Porter, 1985, 1994; Matear et al., 2004), with one key issue being the role of customers in service processes (Ulwick, 2002), as customer involvement in services seems more important than in developing processes in manufacturing (Langeard et al., 1986; Martin and Horne, 1995; Normann, 1991; Vermillion, 1999; Edvardsson et al., 2006). In order to be innovative, a firm must be able to identify opportunities in the market(s) in which it operates, because in a market-oriented organisation interaction with customers is regarded as a key factor for successful business survival (Ennew and Binks; 1996; Martin and Horne, 1993; Ulwick, 2002; Edvardsson et al., 2006).

The resource-based view contradicts that of the market-based by claiming that the essence is not to identify and exploit opportunities in the market place, but to possess rare, scarce and unique resources that enables a firm to develop its innovation potential and innovation activities (Penrose, 1959; Wernerfeldt, 1984; Grant 1996; Prahalad and Hamel, 1990; Connor and Prahalad; 1996 and Eisenhardt and Martin, 2000). The core of the resource-based view is that a firm's innovation ability is grounded in its resources, skills and capabilities, which may fuel innovation processes and activities.

The perspectives on innovations may be subject to debate and contradicting views in the research community, although there is a consensus that "innovation is at the heart of many companies' activities" (Trott, 2005:5). Despite this consensus, different conceptual frameworks (models) have been suggested as to how innovations actually work at the firm level, including those of linear models of innovation, simultaneous coupling models and interactive models of innovations (op.cit.). One prevailing view is that of a process view of innovation, which, according to this line of 
thought, perceives innovation within firms as a management process (Tidd et al., 2005; Trott, 2005). According to this view, a firm's knowledge base within its core functions, including marketing, research and technology, in addition to finance and business planning over time, will impact on the innovation potential of a firm. Similarly, a set of external inputs will influence the innovation process (Tidd et al., 2005).

Thus, the research on service development and innovation seems to be in an early stage of knowledge development since relatively little research has been carried out (Johne and Storey, 1998; de Bretani, 2001; de Jong et al., 2005 Oke, 2007). Thus, how to enhance a firm's innovative potential is a complex issue that involves the effective management of a variety of different activities within an enterprise. So, according to research literature, what are the success factors to service development?

\section{Success factors to service development}

In the research literature, the identification of success factors is a topic of primary concern in relation to service development (de Bretani, 1991; Dörner et al., 2011). According to Dörner et al. (2011), from a firm perspective, the success factors can be grouped into either people-related- or structural factors (de Jong and Vermeulen, 2003).

People-related factors refer to the human element in the developmental stages of services, with concern to the role of customers, the role of front-line employees, the role of service management and the role of backstage personnel (op.cit.). The role of customers refers to how a service provider understands and transforms the needs, wants and preferences of the target customers into the service development process (Matthing et al., 2004), with the essence being to know the markets in which the firm operates and what offers are viable. Contrasting the product development process in manufacturing industries, the customers in service development usually play a more important role (Matthing et al., 2004; Edvardsson et al., 2006). However, how to integrate the customers into service development processes requires more research (op.cit.). Similarly, front-line employees are crucial for developmental purposes, as the involvement of these employees enhances the possibility of successful development and the implementation of innovative services (de Jong and Vermeulen, 2003). Therefore, a firm's front-line employees are at the heart of the innovation process (Martin and Horne; 1993; de Bretani, 2001) due to their interactive and intensive personal interactions with the customers since they are the first to know when the customers are satisfied or dissatisfied with the core service offerings and supplementary services (Lovelock and Wright, 1999). The role taking of service management is also a critical factor to success in service development (Dörner et al., 2011). Top management must establish a firm's corporate vision (Daft, 1999) that encourages and supports innovation initiatives and actions, as well as the creativity processes by the service employees across organisational layers. Similarly, service management must encourage and stimulate the work of multi-functional teams in the processes of innovating a firm's service offerings. Finally, the back-stage personnel may also play a role in service developmental processes (Lovelock and Wright, 1999). Even though they do not have direct customer contacts, they possess knowledge into many technical- and operational aspects of the service offerings, and in this way possess valuable ideas of how to develop the service offerings.

From a firm perspective, structural factors concern the character of the service development process (systematic vs. an unsystematic process), the concrete innovation tools, the use of multi-functional teams and the availability and use of specific resources in addition to market research and market testing (Dörner et al., 2011). In contrast to a systematic development process consisting of defined stages (e.g. Scheuing and Johnson, 1989; Hart and Baker, 1994), an unsystematic process is more "ad hoc" in its orientation with some researchers arguing that service enterprises have a limited use for a systematicor formal process to manage service development (e.g. Martin and Horne, 1992, 1993; Jones, 1995; Kelley and Storey, 2000). 
On the other hand, Dörner et al. (2011) perceive a structured innovation process for services as consisting of three phases: the definition-, the development- and the market launch-phase. Innovation tools concern the remedies or instruments that are available throughout the service development process such as e.g. the use of lead user workshops, blueprinting and customer workshops. The use of multi-functional or cross-functional teams concerns the composition of the teams that may impact on services development and innovation, while a firm's resources may also be decisive for obtaining success in services development. The core argument to this line of thought is that the better the "quality" of the firm's resources, the better a firm's potential for innovation will be. The assumption is that a firm may develop a sustainable competitive advantage by combining the heterogeneous, unique bundle of the firm's resources in innovative ways that its competitors cannot easily imitate (Barney, 1991; Connor, 1991; Wernerfelt, 1984). In the research literature, a set of resource typologies is suggested (Barney, 1991; Dollinger, 1995; Hofer and Schendel, 1978). From a knowledge perspective, a firm's knowledge resources are decisive in order to foster innovation initiatives and actions and in this way obtaining a competitive advantage (Foss, 1997). A key characteristics of knowledge as a resource is that it is not reduced by usage, but can grow (Widding, 2003). Obviously, the quality of a firm's entire resource base is crucial for what management can do in order to foster innovation in the enterprise.

The conclusion on this part is that even though research on service development and innovation is in an early stage of development, the topic has gradually caught the attention of several management researchers with this interesting field of innovation gradually growing and progressing. Thus, how the knowledgebase on this topic advances in the future is of vital academic interest. Several schools of thought have been suggested, though to date (2011), the synthesis perspective seems to be the preferred one. In order to trace influencing factors on service development and innovation, the group categories of people-related- and structural factors (de Jong and Vermeulen, 2003) seem useful as a frame of reference.

\section{Methodology}

The research reported in this paper is a single case study (Merriam, 1998; Yin, 2003), and according to Gummesson (2000:87), "case study research has received growing recognition among groups of management researchers". The case study is particularly applicable and useful when examining a phenomenon about which relatively little is known (Mehmetoglu, 2004; Merriam, 1998; Yin, 2003). Hence, the case study approach is an appropriate research methodology to employ when examining service development on the Hurtigruten.

In this paper, service development is the case to be examined, with the Hurtigruten serving as the research setting. A qualitative approach was chosen to examine the research phenomenon because qualitative methodologies are particularly useful when examining changes and change processes in enterprises (Veal, 2006; Yin, 2003, Gummesson, 2000). For this reason, examining organisational changes such as service development requires a "richness" and "depth" in data that a qualitative research design may provide (Gummesson, 2000). This implies a research paradigm of induction, which is closely associated with a social constructionist viewpoint of scientific knowledge development (Easterby-Smith et al., 1999). In the research literature induction is perceived as "the process of observing facts to generate a theory" (Ghauri and Grønhaug, 2002:14). However, this study does not aim to suggest a theory on service development which is applicable in industries across the service sector, but instead aims to make a contribution to knowledge development on service development in a specific research context: in an explorer cruise line setting.

An examination of previous empirical studies that examines service development reveals the use of multiple research methodologies, which entails both primary- and secondary research information (Booth et al., 2003), and this study is based on both sources of information. Archival information such as annual- and 
internal reports from the shipping lines, served as useful secondary data. Illustratively, an internal report entitled, "Strategic choices after 2001" (Hurtigruten, 1999), provides the rationale and arguments for moving into the competitive international explorer cruise line market. Still, according to Kinnear and Taylor (1991:182), "secondary data often has a "data fit" problem", while primary research information usually offers more specific, targeted and extensive information from respondents who can provide more understanding and insight into the topic under study.

Primary research information was obtained from nine service managers and service personnel including six men and three women. The nine respondents were identified by means of a non probability sampling procedure, that of convenience sampling (Berg, 2007; Finn et al., 2000; Saunders et al., 2003), a procedure which "makes no attempt at representativeness at all" (McQueen and Knussen, 2002:75). The participants were judged to be the most knowledgeable and accessible persons on service development from the time the Hurtigruten's top management and board of directors decided to strategically enter the highly competitive explorer cruise line industry.

In qualitative research, the personal interview is the most commonly used method of data collection (Fielding, 1997; Easterby-Smith et al., 1999). The personal interview has its strength in securing a "depth" and "richness" to the data. In order to carry out long interviews (Berg, 2007), the advices of McCracken (1988) were carefully followed. One important issue, for example, is that the investigator "allows the respondent to tell his or her own story in his or her own terms" (McCracken, 1988:22). This implies that flexibility is encouraged in the course of the interviews, thus implying that the interview guide is not necessarily strictly followed if relevant information comes up during the interviews. The interviews were carried out at the headquarters of the shipping lines in Troms $\varnothing$ and Narvik.

A semi-structured interview guide (Jennings, 2001; McQueen and Knussen, 2002; Saunders et al., 2003) was developed and employed in the study (see Appendix 3 for informative details). During the course of the interviews, each one lasted for approximately one and a half hours, it was essential that the respondents could describe both the totality and details on service development on the Hurtigruten in their own words. In this way, the interviewees could provide extensive data that served as a basis for the analytical procedures. The long interviews with the service managers were conducted during the spring and autumn of 2006 and the winter and spring of 2007.

According to Ghauri and Grønhaug (2002), Mehmentoglu (2004), Merriam (1998), and Johannessen et al. (2004), qualitative data may be analysed in various ways. In this research, the in-depth interviews were tape recorded and transcripts were made, with the transcripts serving as a basis for a thorough content analysis of the information that was collected. An extensive examination of the transcripts was required in order to provide a comprehensive understanding of service development as perceived and reported by the interviewees. Nonetheless, according to Mehmetoglu (2004:139), "there are no distinct and recommendable procedural steps for analysing case study data" (author's translation). Therefore, a challenge would be to employ an analytical procedure that provides a comprehensive account of the results obtained in the study (Gummesson, 2000). In this study, the Merriam's (1998) analytical procedure of three distinct phases was considered useful and applicable in the analysis part of the research: intensive analysis, the development of categories and theory development.

The intensive analysis phase was carried out by an extensive analysis of the interview transcripts, which provided both insight and understanding on the totality, as well as the details of service development on the Hurtigruten. The intensive analysis phase then served as a basis for the attempts to develop a set of categories (Merriam, 1998), which were termed "factors". The identified factors were identified as the set of categories which, according to the interviewees, influenced service development on the Hurtigruten, whereas the theory development phase was covered by an attempt to model how the 
identified factors influenced service development according to the interviewees' information.

According to Gummesson (2000), the issue of quality in empirical studies needs to be taken into consideration. Nevertheless, there are several opinions on how to obtain and secure quality in quantitative studies (Johannessen et al., 2004), and Veal (2006) discusses two axioms of research quality, validity and reliability. Validity is perceived as "the extent to which information collected by the researcher truly reflects the phenomenon being studied" (Veal, 2006:41). The research phenomenon is service development, which is examined in an explorer cruise line context: on the Hurtigruten. The validity of the research findings is closely linked to the recall, understanding and experiences of the respondents. As the respondents were given a sufficient amount of time to recall and rethink how service development was performed over time, the information gradually formed a "pattern", which demonstrated the factors that influenced service development on the Hurtigruten.

Reliability is perceived by Veal (2006:41) as "the extent to which research findings would be the same if the research was to be repeated at a later date with a different sample of subjects". However, since the intention of a single case study "is not to make generalisation but to investigate a "one-off situation" (Clark et al., 1998:103), the case study may contribute to the knowledge field of service development, though it is restricted to a specific context: on the Hurtigruten.

A study that involves people always needs ethical considerations (Johannessen et al., 2004), and Nerdrum (1998) discusses three issues that researchers need to take into account when collecting information from interview subjects. The first issue is the rights of the interviewees to self-determination and autonomy. The second issue is to respect their privacy, and finally, the third issue is to avoid any personal damage to the respondents. In the research reported in this paper, the first issue is particularly relevant, which, according to Silverman $(2005: 258)$, concerns a principle of "informed consent". The respondents were not under any pressure to participate in the research and they joined in voluntarily with both interest and enthusiasm. In the course of the in-depth interviews, they told their "stories" on how service development was carried out on the Hurtigruten with no interruptions from the researcher. Each participant was also informed that he/she could decide to leave the interview for any reason and that the information that was provided would be treated anonymously. To the best of our knowledge, the research did not harm the respondents in any way.

\section{Findings}

Findings for Research Question 1: What key factors influence service development on the Hurtigruten?

The research identified eight influential factors to service development on the Hurtigruten. According to Merriam's (1998) analytical procedure, the identified factors constitute the categories of the study, which were developed by means of a content analysis of the interview transcripts. The factors belong to three main groups:

$\checkmark$ Company internal factors: new leadership, management competencies, management preferences/priorities and strategic orientation;

$\checkmark$ Company external factors: competitive pressure and market preferences;

$\checkmark$ System factors: political frame conditions and industry frame conditions.

\section{Company internal factors}

Four company internal factors were identified in the research, including those of new leadership, management competencies, management preferences/priorities and strategic orientation. The factors will be described in turn.

\section{New leadership}

New leadership has been a dominant trait on the Hurtigruten since the mid 1990s. New leaders have joined the organisations at both the strategic- and operational levels, and "old" leaders have left for several reasons. These frequent shifts in leadership positions may create organisational pressure and stress within the organisations (Hunt, 1997). However, 
organisational turbulence can create energy towards developmental processes (Handy, 1993). As one interviewee put it, " $A$ new leader will introduce new ideas and plans to the organisation". On the other hand, another interviewee expressed the view that, "The continuous shifts in leadership positions took attention away from the product development process and instead focused on economic generating processes, especially how to reduce costs". Thus, new leadership may have a positive as well as negative influence on service development in an enterprise.

\section{Management competencies}

Several interviewees mentioned "management competencies" as a factor that influenced service development on the Hurtigruten. The core competencies of the Hurtigruten shipping lines before the strategic choice of moving into the explorer cruise line market were on technical and operational shipping line management. As expressed by one interviewee, "Why think about markets and travellers when the capacity of the ships was paid for by the Norwegian authorities?' Following a heavy build-up of capacity (tonnage) and fewer subsidies from the Norwegian government, even more economists moved toward the shipping lines giving priority to "cost effective management", as was emphasised by several interviewees. However, in the merged shipping line, the Hurtigruten ASA (2006), a shift in direction is observed, as more emphasis was placed on service development. As one interviewee said: "A new culture seemed to emerge, a culture of services. In this highly new service culture, services and market competencies were more valued than before". Hence, as a consequence of the merger in 2006 and an aim to become a world leader in explorer cruises, there has been a move towards becoming a more innovative and market-oriented enterprise.

\section{Management preferences/priorities}

Management preferences/priorities were an influential factor that was mentioned by several interviewees. Due to the economic turbulence in the shipping lines, top management had given a priority to cost reductions at all organisational levels. As one interviewee said, "The economists were really driving this company." In this way, service development, which is often initiated, planned and driven by service- and marketing managers, came under pressure, with the service managers having to adapt to the dominant economic thinking or "logic of economy" of the top leadership team. As another interviewee said, "In a dispute between an economist and a service marketer in this enterprise, the economist will always be the winner." For this reason, economic reasoning was the prime driver for organisational changes to be made in the enterprises in times of economic turbulence and change. However, gradually, particularly through the 2000s, service development has been given more of a priority.

\section{Strategic orientation}

The research identified strategic orientation as an influential internal factor to service development on the Hurtigruten. Over time, the continuous merger plans of the shipping lines seemed to draw intellectual capacity and interest away from service development toward the economic synergies to be obtained from the merger process. As one interviewee said, which was approved by others, "The merger plans gave priority to strategic thinking about alliances and were at a level far beyond thinking about how to improve and develop new services". Even so, a merger attempt failed in 2004 that created a rather hostile relationship between the shipping lines TFDS and OVDS. One respondent said that "After the merger failure, the entire organisation was exhausted and no one took any initiatives to focus on developing new services." However, as emphasised above, a shift was observed after the successful merger in 2006.

Hence, in the research, a set of company internal factors was identified as being influential to service development on the Hurtigruten. Nevertheless, a set of company external factors were identified as well that will be described next.

\section{Company external factors}

Two company external factors to service development were identified in the research, those of competitive pressure and market preferences. 


\section{Competitive pressure}

Over the last few decades, some international carriers in the cruise line industry have paid more attention to the Norwegian coastline as an arena for cruise operations. Troms $\varnothing$, as one example, has approximately 70 cruise ship arrivals annually (Cruise Statistics, Norway) (see map in Appendix 1 for geographical orientation). Thus, the competitive pressure in the cruise industry along the Norwegian coast has increased, but although some international cruise line companies use Norwegian harbours as part of their sailing routes, the operations are not fully comparable to the Hurtigruten's sailing to 34 harbours from Bergen up north and back from Kirkenes down south (see map in Appendix 1). Although the core product offerings and supplementary services on the Hurtigruten are somewhat different from those of the competitors, one interviewee said that "Obviously the more extensive use of the Norwegian coastline by international cruise line operators has put pressure on the Hurtigruten's management to pay more attention to the competition from the international cruise line carriers". Another interviewee said that "The Hurtigruten product is assessed by the tourists as an expensive and high-class tourism product that is not like "ordinary" cruises". An inspection of the Hurtigruten "price list" confirms this statement, as the prices on the Hurtigruten have increased substantially over the last two decades. The upgrading of the Hurtigruten tourist product has put more emphasis on service quality issues, though a problem emphasised by one interviewee is "The problem of delivering high- class service on all ships in the Hurtigruten fleet." Several interviewees expressed the view that the quality level varied too much on the 11 ships. A conclusion here is that the enhanced competition from international cruise line carriers has exerted a positive impact on the service development onboard the Hurtigruten. Obviously, as shown in service research, enhanced competition may help to gear the processes of renewal and change.

\section{Market preferences}

Last, but not least, the research shows that the market preferences expressed by the tourists themselves may influence service development. One service manager said that
"Customer feedback is important in the further development of the Hurtigruten product. However, what we lack is a systematic plan for how to collect customer information." Another interviewee expressed that "Compared to the old times when we did not give any attention and priority to the tourists, a change came with the new ships, and the tourists became more important compared to the transport of locals and goods". One conclusion that can be drawn from this part is that more emphasis has gradually been placed on markets and customers in relation to business conduct. One example of this is that the merged shipping line has employed a market analyst in order to enhance the customer focus and orientation of the shipping line. As a result of this, in the research two key factors in the research were identified as being influential to service development on the Hurtigruten. In addition, a third group was also identified, which in this paper is termed system factors.

\section{System factors}

Two system factors were identified in the research, political frame conditions and industry frame conditions.

\section{Political frame conditions}

Several of the interviewees commented on the factor, "political frame conditions". One interviewee said that "Obviously the political signals were clear enough; the shipping lines had to generate more income on their own due to the reduction of subsidies from the government authorities". Some interviewees also commented on a $10 \%$ governmental withdrawal of direct economic support for the building of new ships. As one interviewee said "The heavy build-up of new and modern cruise ships during the mid 1990s was influenced to some extent by the withdrawal of shipping yard economic support in Norway. The build-up programme was necessary but under normal circumstances should be carried out on a longer time basis". The heavy build-up of capacity (tonnage) over a short period of time stressed the shipping line's management personnel, particularly the sales force, which had to sell the increased supply capacity to the national- and international markets in times with restricted market budgets. Yet, in this situation, the sales and service personnel 
became more important. As one interviewee mentioned, "Gradually, instead of being viewed as next to economists, we suddenly experienced an upgrading in status, as the company had to rely more on us, the sales force, in order to obtain more sales". Over time, the political frame conditions have changed substantially. However, still (2011), the Hurtigruten receives a substantial amount of money from the Norwegian government for its role as an important means of transport infrastructure along the Norwegian coast.

\section{Industry frame conditions}

In the early 1990s, an economic recession period in Western economies was coming to an end. In Norway, optimism gradually took the lead in businesses after a period of cost cutting and sales reductions, while in the Hurtigruten shipping lines, strategic discussions were carried out primarily concerning the physical transformation of the Hurtigruten fleet from "old" to "new" ships (see Appendix 2 which shows photos of ships within the two categories). In this situation, several interviewees pointed at changes in industry frame conditions as being influential to service development. One interviewee said that "A move from negativism to positivism was experienced in the early 1990s. We now looked ahead. What should the Hurtigruten be like in the future?". This optimism was fueled by a supportive economic atmosphere, as the banks again were in a position to offer attractive loans, and the Norwegian government encouraged and supported the ship yards new building programmes. The same interviewee continued, "The shipping lines were also favoured by supportive tax reductions". Another interviewee expressed that, "Now it was time to speed up again. Whole industries were on the move ahead supported by the economic establishment". We entered a new economic atmosphere supported by attractive and competitive industry frame conditions. This highly new situation ought to be exploited by our company." A third interviewee expressed that, "Obviously, we had to take advantage of the favourable economic conditions after the recession period". As a result, the industry frame conditions after the recession period favourably supported the further planning and development of the Hurtigruten shipping companies, although first and foremost the focus was on the construction of physically solid explorer cruise ships, but gradually more emphasis was also placed on supplementary services such as the quality of the excursion programmes.

An intensive analysis of the interview transcripts yields eight factors, or categories (Merriam, 1998), within three main groups that have influenced service development on the Hurtigruten. According to the interviewees, the most influencing factors to new service development on the Hurtigruten today are competition, and particularly changing market preferences. A statement from one interviewee is quite common: "As new tourist groups decide to travel on the Hurtigruten, their preferences are quite different from the "traditional" tourists". As one example, the Germans do not require the same degree of luxury as the Americans, who have experiences of luxury cruises word-wide". The implication of this statement is that more of a focus on customeroriented service development onboard the Hurtigruten is required.

\section{Findings for Research Question 2: How do the identified factors influence service development on the Hurtigruten?}

Figure 1 below portrays how the identified factors influence service development on the Hurtigruten:

The model depicted in Figure 1. is derived from the research findings to Research Question 1. The model is contextual and shows that service development on the Hurtigruten is influenced by three primary groups, which are termed company internal-, company external- and system factors. What makes the model contextual in particular is the system factor, political frame conditions, which demonstrates that over time the Norwegian government has spent a substantial amount of tax payers' money in the buying up of the transport capacity on the Hurtigruten.

Figure 1 depicts that the three groups constitute a relational system as they interact. The system factors influence and are influenced by the company internal factors, 


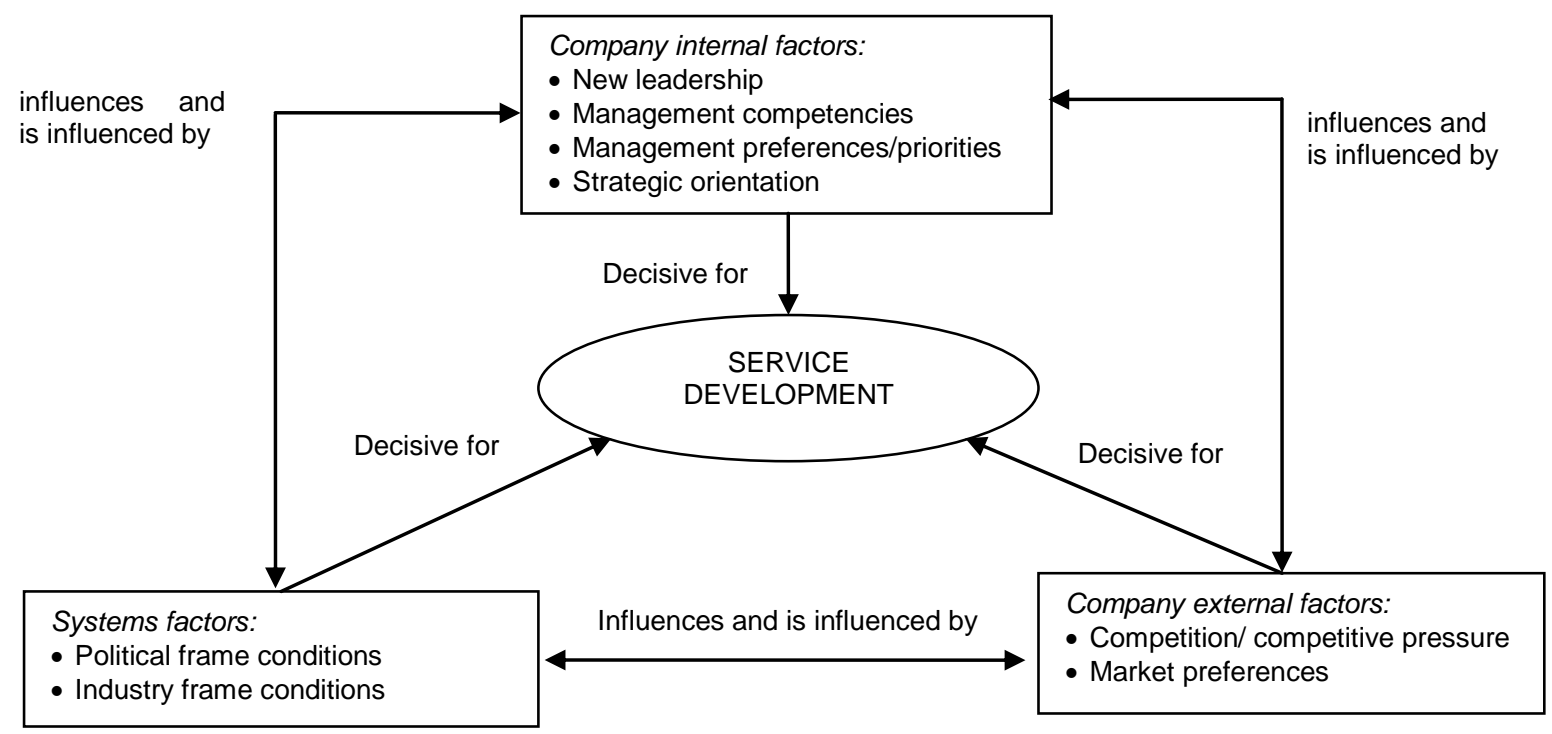

Figure 1. The influential factors for service development: The Hurtigruten case

while the company internal factors similarly influence and are influenced by the company external factors. Finally, the company external factors impact and are impacted by the system factors.

The line of argumentation is that service development on the Hurtigruten was initiated as a result of the political signals of the early 1990s in relation to a substantial reduction in economic support (subsidises) from the Norwegian government day to day operations of the Hurtigruten. Likewise, an economic recession in 1989 and 1990 also influenced the development of the Hurtigruten fleet. In order to support the ship-yards and ship owners in times of economic set-backs, the Norwegian government changed the industry frame conditions by economically supporting industry sectors. The Hurtigruten's management utilised the situation by ordering new ships beyond what would have been done under "normal" economic circumstances. Consequently, system factors influenced management priorities and strategic orientation. The alarming political signals forced the strategic top management of the shipping lines to act, and they decided to become a world-leader in explorer cruises in polar waters. As a result of the strategic reorientation initiated and planned 64 by top management, new and modern explorer cruise ships gradually replaced the "old" ships (see Appendix 2 for an illustration). This buildup in transport capacity not only became a challenge, but also an opportunity to gear up developmental processes on the Hurtigruten. In these times of change, international carriers also observed the market potential of the Norwegian coast and fjords that made the Norwegian coast line as a geographical area for cruise operations. Thus, the competitive pressure increased, which created even more pressure on the Hurtigruten's management to act in order to become more competitive in this new competitive- and market situation. Similarly, gradually and particularly through the 2000s, new customer groups with shifting market preferences started paying attention travelling on the Hurtigruten. Because of this, Hurtigruten management had to give even more priority to developmental change processes such as the service development in order to cope with the environmental changes.

As emphasised, the model suggested in Figure 1 is contextual. What make the model contextual are the system factors that derive from the prevailing political "logic" of the social democratic government in Norway. Industrial development is not left to "market forces" only, 
but in accordance with a social democratic "logic", is impacted by political initiatives and actions. However, both company internal- and external factors may have relevance beyond the research factors, as according to service theory, customers, competitors and leadership influence change- and developmental processes.

\section{Discussion}

Innovation in enterprises is highly complex, which implies the need for effective management of a variety of different activities (Tidd et al., 2005), and, according to theory, innovation needs to be viewed as a management process, and not as a single event (Trott, 2005). The process view of innovation is confirmed by the research carried out on the Hurtigruten, and a set of factors impact on service development, as portrayed in the Figure 1.

According to Trott (2005), two schools of thought have been suggested as prime "drivers" of service development within innovation literature, those of a market-basedand a resource-based view. The resourcebased view, which focuses on a firm and its resources, skills and capabilities, seems to apply well in the initial phase of service development on the Hurtigruten, which was started by the introduction of new ships in the early 1990s and ended in 2006 by the merger of two shipping lines into one, the Hurtigruten ASA. During this period, the physical product, the new ships with the core physical facilities, constituted the renewal and changes on the Hurtigruten, in which the service development process features the traits of a top-down model. Strategic leadership took the lead in developmental- and change processes and as the Hurtigruten faced economic turbulence and substantial deficits in its accounts, the focus and priority were on cost reductions and organisational issues in the shipping lines. Service development was not given a priority other than in physically and operationally developing the ships. Nonetheless over time, and in particular after 2006, service development has gradually been upgraded to the current date by especially developing the supplementary services of the core Hurtigruten product. Though top management still plays a key role in service development by the hiring and staffing of market managers and personnel, service development is, to a greater extent, reflected by a change towards a market focus and orientation.

According to theory (Trott, 2005), there are two types of linear models, those of a technology push and of a market pull. In the period leading up to 2006, the model was that of a technology push character, as the focus was on the appearance of the (physical) ship and the construction of the ships prime facilities, and this was done by an examination of explorer cruise ships already in operation in polar waters. The linear model on the Hurtigruten started with a competitor analysis phase, followed by a design phase and ending with the construction/manufacturing of the ships as the final phase. However, as a result of the merger in 2006, the resource-based view was gradually replaced by a market-based view, the competitors and customers impacted more on the company's innovation activity (Slater and Narver, 1994; Porter, 1985, 1994). Thus, through the 2000s, service development on the Hurtigruten has been influenced by a set of company external factors, such as those of competitive pressure and market preferences. As a fact, the Hurtigruten has gradually faced enhanced competition from international cruise line carriers. For example, the Crystal Cruises has offered the product "14 Night Wonders under the Midnight Sun" on-board the Crystal Serenity, while the Cunard has similarly promoted and sold the product "14 Night Land of the Midnight Sun", on the famous Queen Elisabeth II. Therefore, as more cruise line carriers have exploited the market possibilities offered along the long Norwegian coast by its fjords and settlements, the competitive pressure has enhanced. Obviously, enhanced competition must be met by developmental actions by the service management of the Hurtigruten. Similarly, as the supply side of the explorer cruise line industry has increased, a change of markets (Biederman, 2008) has subsequently followed. As evidenced by Poon (1993), customers' needs, desires and preferences changes and suppliers must adopt accordingly. On the Hurtigruten, there has been a gradual increase in the number of younger, adventure seeking people, which have resulted 
in more supplementary services being included in the Hurtigruten's product in order to cope with shifting customer preferences. This change is evidenced by new service offering today (2011), particularly in relation to a set of exotic events fitted into the service product portfolio. Thus, from 2006 to date (2011), a move to a coupling model has been the case as the components mentioned above interact, with an important trend being that the role of top management has gradually been reduced and has been replaced by the role of service mangers in the service development processes.

As outlined in the literature section, a set of factors impacted on service development (de Jong and Vermeulen, 2003). In this research, the key role of top management as a peoplerelated factor is confirmed as an essential factor, which impacts on service development. However, as evidenced in service development research (e.g. Dörner et al., 2011), the service employees are at the heart of innovation, although this is not a finding of the research on the Hurtigruten. In theory, as emphasised, the role of competition and market orientation are in evidence with the role of the factors termed company external factors, and these factors are to some extent confirmed in the research as the needs, wants and preferences of the tourists have been particularly addressed after the merger in 2006. Similarly, in theory, a set of structural factors are witnessed as important for services development (de Jong and Vermeulen, 2003). First, the research carried out reveals a top-down process, initiated, planned and implemented from the top. In this way, the process portrays the features of a management process. Even so, the research on the Hurtigruten was not conducted by multifunctional teams, but, up to 2006 in particular, was a top management activity. However, after 2006, by the employment of several service mangers, middle-management has played an enhanced role in service development on the Hurtigruten. Finally, as shown in this research, system factors have influenced service development on the Hurtigruten, as the Norwegian government has spent an enormous amount of tax payers' money to buy transport capacity on the Hurtigruten. The logic for this has been that the Hurtigruten has been an important means of transportation for the scattered population along the long Norwegian coast. However, because of a gradual change and development of infrastructure, such as a net of speed boats and airports, the role of the Hurtigruten has changed. Still, the Norwegian government has continued to buy transport capacity, though there has been a slow by steady decline in economic support. Similarly, the industry frame condition has changed over time as a result of the free market thinking philosophy, which to date dominates in political circles in Norway.

\section{Implications and conclusions}

Theoretical implications

The present study has provided an understanding and insight on service development in a cruise line context by examining this important topic in relation to the Hurtigruten, including the acquisition of a series of invigorating insights that has theoretical implications.

First, in connection to the research findings on company internal factors, the research supports the role of new leadership and management when new leaders enter an organisation. According to leadership theory (Daft, 1997), new leaders usually imply changes and actions in business conduct. Because of this, the research carried out supports the contingency view of organisational change (Hunt, 1997).

Second, as a linkage to company external factors, the research confirms the role played by competition and market orientation in the developmental processes of innovation (Trott, 2005). As evidenced in innovation theory (de Jong and Vermeulen, 2003; Dörner et al., 2011), a set of drivers to services development has been identified, out of which the role of competition and a market approach has been seen in this research.

Third, in conjunction with the research findings on system factors, the research shows the role of contextual factors, which are factors beyond the control of the company that play a role in the developmental processes of services (Tidd et al., 2005). Hence, enterprises' adoption to 
contextual boundaries is supported by this research.

\section{Managerial implications}

Thus far, the research has documented a set of factors impacting service development on the Hurtigruten that has implications for management. First, the company internal factors depict the role of leadership and management in change processes. The factors identified on the Hurtigruten reveal that in large part service development is carried out as a top-down process, thereby implying that top management decides what firm resources that are allocated to service development. Nonetheless, when top management prioritises cost reductions across organisational layers, financial- and organisational resources for new service development may be scarce and limited. However, reducing the spending on new service development today may become a "cost" tomorrow as a result not having a competitive and qualitative service product as perceived by the customers and valued by the service employees. Hence, in accordance with this research, more of an emphasis should be placed on service development, thus building up the process by using multi-functional teams, as well as integrating the service employees more intensively in the process.

Second, the research exhibited two company external factors that influence service development on the Hurtigruten. Since the competitive pressure has enhanced and the market preferences of the tourists are constantly subject to change, management is advised to put more of an emphasis on identifying and closely monitoring both their prime competitors and the prime travel markets. Yet, as younger, more adventure seeking people are increasing in numbers on the Hurtigruten, the tourists have become more diversified. As a consequence and in line with this research, there is a need for a stronger build-up of market analyst competencies for the Hurtigruten ASA shipping line.

Third, the research showed that two system factors, those of political- and industry frame conditions, exerted an impact on service development on the Hurtigruten. Nevertheless, these factors are subject to changes over time.
The political frame conditions are still operative today (2011), as the Hurtigruten's transport capacity to some extent has been paid for by the Norwegian government, though the government's support has been gradually reduced. Similarly, the industry frame conditions are changing as a result of the prevailing economic system, the free market philosophy, although in these times of economic turbulence (2011), the Norwegian government has been attempting to stimulate the economy by e.g. financial support to some export-oriented sectors. Therefore, as the role of the systems factors declines, management needs to focus even more on those factors that are influential by their own initiatives and actions. According to innovation research, a key success factor of business conduct is the ability to innovate (Trott, 2005). Consequently, the Hurtigruten's management is advised to put more energy into service development processes in the future.

\section{Conclusions}

The research has provided insight and understanding into service development in a cruise line context through the study of this phenomenon on the Hurtigruten. The case study design has allowed a thorough examination of service development in a highly interesting research context: that of the Hurtigruten.

In order to examine service development on the Hurtigruten, a qualitative research design was employed in the study through the collection of primary research information from service managers and service personnel. The interviewees were assessed to be the most knowledgeable persons in relation to service development on the Hurtigruten from the time the "new" ships entered the fleet in the early 1990s. In order to collect the information, the data was approached inductively. The research identified eight influential factors on service development within three main groups: those of company internal-, company external- and system factors. By building on the influential factors, a model is offered that depicts how the different factors interact. However, since the research has been carried out as a single case study (Clark et al., 1998), the research findings 
are restricted to the specific research setting of the Hurtigruten only.

However, the research conducted may suffer from limitations and challenges, with the first issue under debate being the selection of informants. Have important informants been omitted? However, the convenience sampling seems to include the most knowledgeable persons on service development processes. Second, the research relies heavily on the memory of the informants. To what degree do the respondents correctly remember the service experiences and events? In this respect, the research undertaken faces the same challenges as in all retrospective studies (Johannessen et al., 2004). Nevertheless, their closeness and insights into the research phenomenon provide validity to the research findings. Third, the time of the data collection may be questioned, even though at the time of the data collection (2006 and 2007), service development on the Hurtigruten was brought to a level quite equal to what it is today. Consequently, at the time of the data collection the core service offering and supplementary services on the Hurtigruten were quite similar to what they are today, thus assuring a correspondingly high relevance and validity of the data.

Still, more research on service development is required, with one option being to carry out a qualitative follow-up study that would provide new data on the status of service development on the Hurtigruten. Such data will also be beneficial in order to carry out a comparative study, while simultaneously tracing changes in service development. Another option is to expand the research focus by including more cruise line suppliers in a follow-up study. By doing this, more knowledge on service development will be obtained on the cruise line industry as a whole.

\section{References:}

Adams, R., Bessant, J., \& Phelps, R. (2006). Innovation management measurement. International Journal of Management Reviews, 8(1), 21-47.

Alam, I. \& Perry, C. (2002). A customer-oriented new service development process. Journal of Services Marketing, 16(6), 515-534.
Barney, J. B. (1991). Firm resources and sustained competitive advantage. Journal of Management, 17(1), 99-120.

Barras, R. (1986). Towards a theory of innovation in services. Research Policy, 15, 161-173.

Barras, R. (1990). Interactive innovation in financial and business services: The vanguard of the service revolution. Research Policy, 19, 215-237.

Berg, B.L. (2007). Qualitative research methods for the social sciences. Pearson.

Biederman, P.S. (2008). Travel and tourism: An industry primer. Pearson: Prentice Hall.

Bitner, M.J., Brown, S.W. \& Meuter, M.L. (2000). Technology infusion in service encounter. Journal of the Academy of Marketing Science, 28(1), 138-149.

Booth, W.C., Colomb, G.G., \& Williams, J.M. (2003). The craft of research. The University of Chicago Press.

Clark, M., Riley, M., Wilkie, E. \& Wood, R.C. (1998). Researching and writing dissertations in hospitality and tourism. International Thompson Business Press, London.

Connor, K. R. (1991). A historical comparison of resource-based theory and five schools of thoughts within industrial organization economics: Do we have a theory of the firm? Journal of Management, 17(1), 121154.

Connor, K. R. \& Prahalad, C. K. (1996). A resource-based theory of the firm: Knowledge versus opportunism. Organization Science, 7(5), 477-501.

Coombs, R., \& Miles, I. (2000). Innovation, measurement and services, In J.S Metcalfe, and I. Miles, (eds) Innovation systems in the service economy. Measurement and case study analysis. Kluwer Academic, Boston, MA, pp. 85-103.

Daft, R. L. (1999). Leadership: Theory and practice. The Dreyden Press.

D'Aveni, R. (1994). Hyper-competition: The dynamics of strategic maneuvering. Basic Books, New York, NY.

de Bretani, U. (1991). Success factors in new developing new business services. European Journal of Marketing, 25(2), 3359.

de Bretani, U. (1995). New industrial service development: Scenarios for success and failure. Journal of Business Research, 32, 93-103.

de Bretani, U. (2001). Innovative versus incremental new business services: 
Different keys for achieving success. Journal of Product innovation Management, 18(3), 169-187.

de Jong, J.P.J. \& Vermeulen, P.A.M. (2003). Organizing successful new service development: A literature review. Management Decision, 41(9), 844-858.

de Jong, J., Bruins, A., Dolfsma, W., \& Meijaard, J. (2005). Innovation in service firms explored: What, how and why?. EJM Business and Research. Zoetemeer.

de Vries, E.I. (2006). Innovation in services in networks of organizations and in the distribution of services. Research Policy, 35, 1037-1051.

Den Hertog, P. (2000). Knowledge-intensive business services as co-producers of innovation. International Journal of Innovation Management, 4, 491-528.

Djellal, F. \& Gallouj, F. (2001). Patterns of innovation organization in service firms: Postal surveys results and theoretical models. Science and Public Policy, 28(1), 57-67.

Dollinger, M. J. (1995). Entrepreneurship, strategies and resources. New Jersey: Prentice Hall,

Drejer, I. (2004). Identifying innovation in surveys of services: A Schumpeterian perspective. Research Policy, 33, 551-562.

Droege, H., Hildebrand, D., \& Forcada, M., A., H. (2009). Innovation in services: Present findings, and future pathways. Journal of Service Management, 20(2), 131-155.

Drucker, P.E. (1985). Innovation and Entrepreneurship. Oxford: ButterworthHeinemann.

Dörner, N., Gassman, O., \& Gebauer, H., (2011). Service innovation: Why is it so difficult to accomplish? Journal of Business Strategy, 32(3), 37-46.

Easterby-Smith, M., Thorpe, R. \& Lowe, A. (1999). Management research - an introduction. Thousand Oaks: Sage Publications.

Eastingwood, C.J (1986). New product development for service companies. Journal of Product Innovation Management, 3(4), 264-275.

Eastingwood, C.J. \& Storey, C.D (1995). The impact of new product development projects on the success of financial services. Logistics Information Management, 8(4), 35-40.

Edvardsson, B., Haglund, L. \& Mattsson, J. (1995). Analysis, planning, improvisation and control in the development of new services. International Journal of Service Industry Management, 6(2), 24-35.

Edvardsson, B., Gustafsson, A., Kristensson, P., Magnusson, P., \& Matthing, J. (2006). (eds.) Involving customers in new service development. Imperial College Press.

Eisenhardt, K. M. \& Martin, J. K. (2000). Dynamic capabilities: What are they? Strategic Management Journal, 21, 1105-1121.

Ennew, C.T. \& Binks, M.R. (1996). Good and bad customers: the benefits of participating in banking relationship. International Journal of Bank Marketing, 14(2), 5-13.

Fielding, N. (1997). Qualitative interviewing in Gilbert, N. (ed.) Researching social life. London: Sage Publications.

Finn, M., Elliott-White, M. \& Walton, M. (2000). Tourism \& leisure research methods. Pearson Longman.

Fitzsimmons, J. A., \& Fitzsimmons, M.J. (2000). New Service Development: Creating Memorable Experiences. Thousand Oaks: Sage Publications.

Foss, N. J. (1997). Resources and strategy: A brief overview of themes and contributions. In N. J. Foss, (ed), Resources, firms and strategies: A reader in the resource-based perspective (pp. 3-18). Oxford: Oxford University Press.

Gadrey, J., Gallouj, F., \& Weinstein, O. (1995). New modes of innovation: How services benefit industry. International Journal of Service Industry Management, 6(3), 4-16.

Gallouj, F. (1998). Innovating in reverse: Services and the reverse product cycle. European Journal of Innovation Management, 1(3), 123-138.

Gallouj, F. (2002). Innovation in services and the attendant old and new myths. The Journal of Socio-Economics, 31, 137-154.

Gallouj, F., \& Weinstein, O. (1997). Innovation in services. Research Policy, 26, 537-556.

Ghauri, P. \& Grønhaug, K. (2002). Research methods in business studies. A practical guide. Prentice Hall.

Grant, R. M. (1996). Prospering in dynamicallycompetitive environments: Organizational capability as knowledge integration. Organization Science, 7, 375-387.

Grönroos, C. (2000). Service management and marketing. A customer relationship management approach. Chichester: John Wiley \& Sons, Ltd.

Gummesson, E. (2000). Qualitative methods in management research. Sage Publications. 
Service development: Modelling influencing factors by employing the Norwegian Coastal Voyage (Hurtigruten) as a case.

Handy, C. (1993). Understanding organizations. Penguin.

Hart, S.J. \& Baker, M.J. (1994). The multiple convergent processing model of new product development. International Marketing Review, 11(1), 77-92.

Hofer, C. W. \& Schendel, D. (1978). Strategy formulation: Analytical concepts. West Publishing.

Hoffman, K.D. \& Bateson, J.E.G. (1997). Essentials of services marketing. The Dryden Press.

Howells, J. (2006). Where to from here for services innovation? Paper presented in the Knowledge Intensive Services Activities (KISA) Conference, 22 March, Sydney.

Hunt, J.W. (1997). Managing people at work. McGraw-Hill.

Hurtigruten (1999). Strategic choices after 2001. Company report.

Jennings, G. (2001). Tourism research. John Wiley \& Sons Australia, Ltd.

Johannessen, A., Kristoffersen, L., \& Tufte, P.A. (2004). Forskningsmetode for økonomiskadministrative fag. Abstrakt Forlag.

Johannessen, J.A., Olsen, B., \& Olaisen, J. (1997). Organizing for innovation. Long Range Planning. 30(1), 96-109.

Johne, A. \& Storey, C. (1998). New service development: A review of the literature and annotated bibliography. European Journal of Marketing, 32(3/4), 184-251.

Jones, P. (1995). Developing new products and services in flight catering. International Journal of Contemporary Hospitality Management, 7(2/3), 24-28.

Kandampully, J.S. (2007). Service management. The new paradigm in hospitality. Pearson Prentice Hall.

Kelly, D. \& Storey, C. (2000). New service development: Initiation strategies. International Journal of Services Industry Management, 11(1), 45-62.

Kim, W.C. \& Mauborgne, R. (1999). Strategy, value creation and the knowledge economy. Sloan Management Review, 40(3), 41-54.

Kinnear, T.C. \& Taylor, J.R. (1991). Marketing research: An applied approach. New York: McGraw-Hill.

Langeard, E., Reffait, P. \& Eigler, P. (1986). Developing new services, In $M$. Venkatesan, D. M. Schmalensee, and C. Marshall (eds.) Creativity in services marketing, American Marketing Association, Chicago IL.
Leiponen, A. (2005). Organization of knowledge and innovation: The case of Finnish business services. Industry and Innovation, 12(2), 185-203.

Lovelock, C.H. Patterson, P.G. \& Walker, R.H. (2001). Services marketing: Asia and Pacific perspective. Sydney: Prentice-Hall.

Lovelock, C. \& Wright, L. (1999). Principles of service marketing and management. Prentice Hall.

Martin, C.R. \& Horne, D.A. (1992). Restructuring toward a service orientation: The strategic challenge. International Journal of Service Industry Management, 3, 25-38.

Martin, C.R. \& Horne, D.A. (1993). Services innovation: Successful versus unsuccessful firms. International Journal of Service Industry Management. 4(1), 49-65.

Martin, C.R. \& Horne, D.A. (1995). Level of success inputs for service innovations in the same firm. International Journal of Services Industry Management, 6(4), 4056.

Matear, S., Gray, B.J. \& Garrett, T. (2004). Market orientation, brand investment, new service development, market position and performance for service organisations. International Journal of Service Industry Management, 15(3), 284-301.

Matthing, J., Sanden, B., \& Edvardsson, B. (2004). New service development: learning from and with customers. International Journal of Service Industry Management, 15(5), 479-498.

McCracken, G. (1988). The long interview. A Sage University Paper.

McQueen, R. \& Knussen, C. (2002). Research methods for social science. Prentice Hall.

Merriam, S.B. (1998). Qualitative research and case study applications in education. Jossey-Bass Publishers.

Mehmetoglu, M. (2004). Kvalitativ metode for merkantile fag. Fagbokforlaget.

Menor, L. J., Tatikonda, M. V., \& Sampson, S. E. (2002). New service development: Areas for exploitation and exploration. Journal of Operations Management, 20, 135-157.

Merriam, S. B. (1998). Qualitative research and case study applications in education. Jossey-Bass Publishers. San Francisco.

Narver, J.C. and Slater, S.F. (1990). The effect of a market orientation on business profitability. Journal of Marketing, 54(4), 20 35.

Nerdrum, P. (1998). Mellom sannhet og velferd. Etiske dilemmaer i forskning belyst ved et 
eksempel. Notat - Høgskolen i Oslo, avdeling for Økonomi-, Kommunal- og Sosialfag.

Nijssen, E.J., Hillebrand, B., Vermeulen, P., \& Kemp, R.G.M (2006). Exploring product and service innovation similarities and differences. Research in Marketing, 23, 241-251.

Normann, R. (1991). Service management: strategy and leadership in services business. New York: John Wiley \& Sons.

Oke, A. (2007). Innovation types and innovation management practices in service organizations. International Journal of Operations \& Production Management, 27(6), 564-587.

Penrose, E. (1959). The theory of the growth of the firm. Basil Blackwell Publisher.

Poon, A. (1993). Tourism, technology and competitive strategies. CAB International.

Porter, M.E. (1985). Competitive advantage. New York: The Free Press,.

Porter, M.E. (1994). Towards a dynamic theory of strategy. Strategic Management Journal, 12, 95-117.

Prahalad, C. K. \& Hamel, G. (1990). The core competence of the corporation. Harvard Business Review, 68(3), 79-91.

Rothwell, R. (1992). Successful industrial innovation: Critical factors for the 1990s. $R \& D$ Management, 22, 221-237.

Saunders, M., Lewis, P. \& Thornhill, A. (2003). Research methods for business students. Prentice Hall.

Scheuing, E.E. \& Johnson, E.M (1989). A proposed model for new service development. Journal of Services Marketing, 3(2), 25-35.

Silverman, D. (2005). Doing Qualitative Research. SAGE Publications.

Slater, S.F. and Narver, J.C. (1994). Does a competitive environment moderate the marketing orientation-performance relationship? Journal of Marketing, 58(1), 46-55.

Spohrer, J. (2008). Services sciences, management, and engineering (SSME) and its relations to academic disciplines, In $B$. K. Strauss, A. Kremer, and A. Luhn (eds), Services Science: Fundamentals, Challenges and Future Developments, Springer, Frankfurt, pp. 11-40.

Sundbo, J. (1997). Management of innovation in services, The Services Industries Journal, 17(3), 432-455.
Sundbo, J., Orfila-Sintes, F., \& Soerensen, F. (2007). The innovative behavior of tourism firms - comparative studies of Denmark and Spain. Research Policy, 36, 88-106.

Tidd, J., Bessant, J., \& Pavitt, K. (2005). Managing innovation. John Wiley \& Sons, Ltd.

Toffler, A. (1981). The third wave. London: Pan Books.

Trott, P. (2005). Innovation management and new product development. Prentice Hall.

Ulwick, A.W. (2002). Turn customer input into innovation. Harvard Business Review, 80(1), 91-97.

Yin, R.K. (2003). Case study research: Design and methods. Thousand Oaks: Sage Publications.

Veal, A.J. (2006). Research methods for leisure and tourism. Pitman Publishing.

Vermillon, M.R. (1999). Product development in service industries. Report on 1998 PDMA International Conference, PDMA Visions, Vol. XXIII No. 1, January, p. 16.

Wernerfelt, B. (1984). A resource-based view of the firm. Strategic Management Journal, 5(2), 171-180.

Widding, L. $\varnothing . \quad$ (2003). Bygging av kunnskapsreservoarer $i$ teknologi-baserte nyetableringer. PhD thesis, Høgskolen i Bodø, Bodø, Norway. 
Appendix 1. Informative details and the sailing route of the Hurtigruten (2011).

On the July 2, 1893, the Norwegian steamship D/S Vesteraalen embarked on a voyage from Trondheim to Hammerfest. Approximately 70 hours later, the ship successfully arrived in Hammerfest. Three weeks earlier the Norwegian Parliament had decided to establish a route along the Norwegian coastline from Trondheim to Hammerfest. This was a new and quite astonishing idea, to sail both day and night along one of the most weather-beaten coastlines in the world under all climatic conditions. Despite skepticism, and even severe resistance from experts in Norwegian sea transport, the Norwegian Coastal Voyage, or Hurtigruten, which is the brand name, became a logistical success in sea transport. In 1898 , the route was extended to Bergen down south, and from 1908 to Kirkenes up north. Today, more than 100 years later, the Hurtigruten has become a tourist attraction product of significant importance in Norway, comprising 2500 nautical miles, 34 ports of call, 11 ships and an 11 return voyage Bergen Kirkenes. Appendix 1 shows a map of the travel route as it is today (2011).

The sailing route of the Hurtigruten

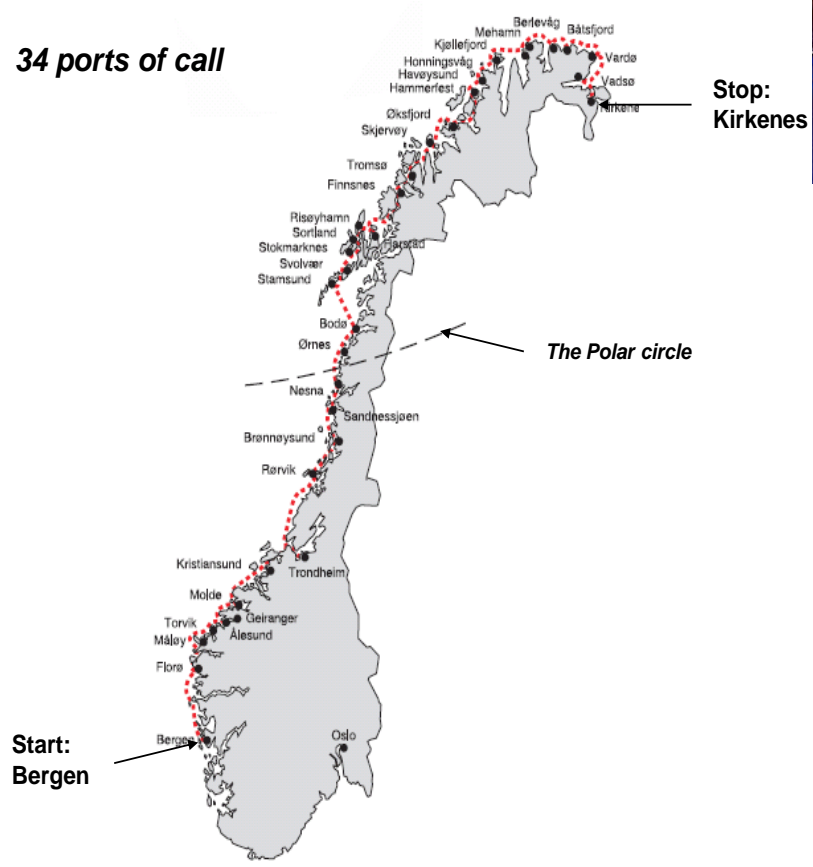

Appendix 2: Examples of the "old" and the "new" Hurtigruten.

MS Håkon Jarl (1952): An example of the "old" Hurtigruta.

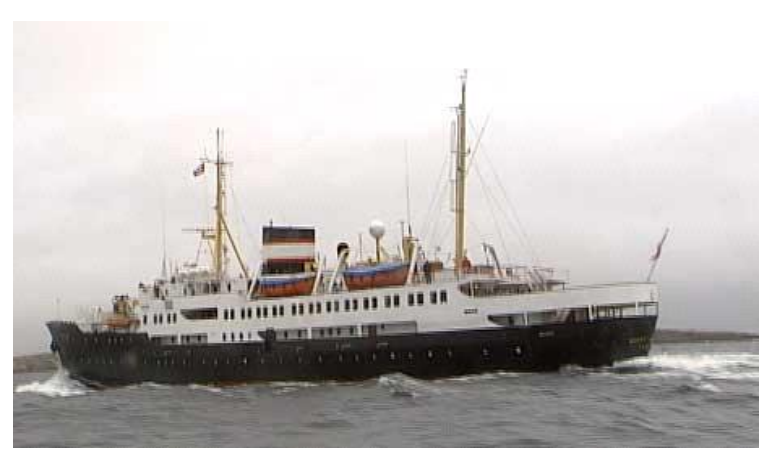

MS Nord Norge (1997): An example of the "new" Hurtigruta.

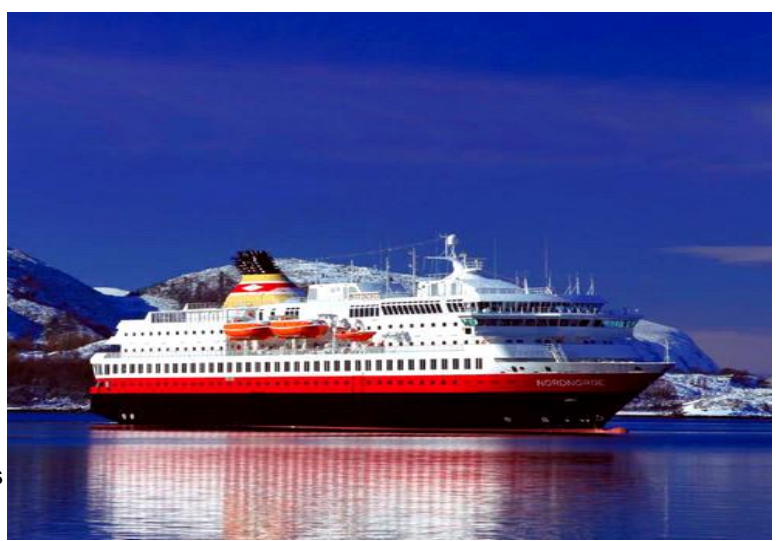


Appendix 3:

Interview guide: Information on service development on the Hurtigruten

1. Introduction to the interview: This is about the researcher, the research project, the questions, the anonymity of the interviewee, the rights of the interviewees etc.

2. The research questions:

$\checkmark$ What key factors influence service development on the Hurtigruten?

$\checkmark$ How do the identified factors influence the service development?

\section{3: Questions to the interviewees:}

\section{Research Question 1 and 2:}

$\checkmark \quad$ Please, tell about service development on the Hurtigruten.

$\checkmark \quad$ Please, explain in your own words what factors you consider important in the process of service development on the Hurtigruten.

$\checkmark \quad$ Can you please elaborate more on the most influential factor, the second most etc.?

$\checkmark \quad$ Please, can you go into more detail on each of the factors that you have mentioned?

\section{Follow up questions:}

$\checkmark \quad$ What do you consider to have been the most supporting factors to service development on the Hurtigruten? $\checkmark \quad$ What do you consider to have been the main barriers to new service development on the Hurtigruten?

$\checkmark \quad$ Please, elaborate more on what you consider the most important barrier, the second most, etc.

$\checkmark \quad$ Please explain in your own words what you consider to be the key characteristics/features/traits of service development on the Hurtigruten.

$\checkmark \quad$ Please elaborate more on the outlined characteristics/features/traits.

$\checkmark$ Please, explain how you perceive the role of actors in services development on the Hurtigruten (competitors, customers, service management/leadership and service employees - both front stage- and back stage personnel).

$\checkmark \quad$ In your opinion, what should be done in order to improve service development on the Hurtigruten?

\section{Ending the interview:} to add?

$\checkmark \quad$ Is there anything the interviewee wants

$\checkmark \quad$ Thank the respondent for participating in the research. 